\title{
The Chamberlen family (1560-1728) and obstetric forceps
}

\author{
Peter M Dunn
}

The invention of obstetrics forceps in the 17th century represented a critically important technical advance in the management of childbirth. It was particularly timely in that the new disease, rickets, was becoming widespread and with it, dystocia due to pelvic deformity. The story of the forceps is bound up with five generations of the Chamberlen family (fig 1). ${ }^{1-5}$

Peter Chamberlen, later known as "the elder," was born in Paris in 1560, the first son of a Huguenot surgeon, William Chamberlen and his wife Genevieve Vignon. Forced to flee because of religious persecution, the family reached Southampton in 1569 where a second son, also named Peter, was born in 1572. Both sons followed their father's profession, becoming barber surgeons and well known practitioners of midwifery.

Peter the elder moved to London in 1596 and became surgeon and accoucheur to Queen Anne, wife of James I. His younger brother followed him to London in 1600. Both had joined the Barber Surgeons Company, first incorporated in 1461 under the reign of Edward IV, and both were in frequent trouble with the Company for minor offences such as failing to attend lectures. Peter the elder also came into serious conflict with the College of Physicians (incorporated in 1518 under a charter granted by Henry VIII) for prescribing medicines contrary to the rule of the College. In 1612 he was committed to Newgate prison for this offence and only released after the intercession of the Lord Mayor of London and the Archbishop of Canterbury. In 1620 it was Peter the younger's turn to be prosecuted by the College, but he was able to defend himself with a letter from the Lord Chamberlain.

In 1616 the brothers supported a "humble petition of the midwives in and about the city of

University of Bristol
Department of Child
Health
Southmead Hospital
Southmead
Bristol
BS10 5NB
P M Dunn
Correspondence to:
Professor Peter Dunn.

London ... that the said midwives be incorporated and made a Societye." The petition was addressed to Sir Francis Bacon, a member of the Privy Council and to the King, who then referred it to the College of Physicians for their consideration. The College recognised the need to improve the skill of the midwives who were for the most part very ignorant, and yet denied the petition stating: "Nevertheless they think yt neither necessary nor convenient that they should be made a Corporation to govern within themselves a thing not exampled in any Commonwealth." The College added that its senior members would be happy to instruct the midwives in their art and to advise the Bishop on which should be approved to practise midwifery. They also admonished Peter the younger for having "impudently advocated the cause of these women" and for implying that he, his brother, or any obstetric surgeon could know more about midwifery than physicians.

There is no record of Peter the elder ever marrying. In 1628 he is known to have attended the new Queen, Henrietta Maria, daughter of Henry IV of France and wife of Charles I, when she miscarried at Greenwich. He died in 1631 at the age of 71 .

Peter the younger married Sara de Laune, daughter of a French Protestant minister, whose brother Gideon de Laune helped to found the Worshipful Society of Apothecaries of London. They had eight children, one of whom, also named Peter, became a famous physician accoucheur. Peter the younger died in London in 1626 at the age of 57 and was buried at Downe in Kent.

It is not certain which of the brothers invented the obstetric forceps which were to remain a family secret for more than 100 years. Aveling (1882), however, gives that honour to Peter the elder. The Chamberlens went to fantastic lengths to keep their secret. According to Graham (1950) they are said to have arrived at the house of the woman to be delivered in a special carriage. They were accompanied by a huge wooden box adorned with gilded carvings. It always took two of them to carry the box and everyone was led to believe that it contained some massive and highly complicated machine. The labouring woman was blindfold lest she should see the "secret." Only the Chamberlens were allowed in the locked lying-in room, from which the terrified relatives 


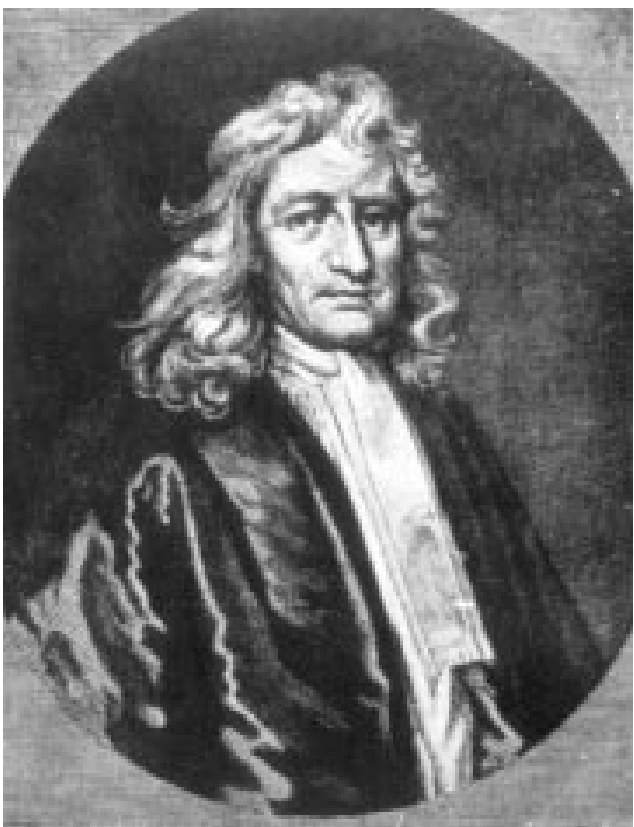

Figure 2 Dr Peter Chamberlen (1601-83).

heard peculiar noises, ringing bells, and other sinister sounds as the "secret" went to work.

Peter, son of Peter the younger, and known as Dr Peter Chamberlen, was born in 1601 (fig 2). He studied at Merchant Taylor's School and in 1615 entered Emmanuel College, Cambridge. Studies followed at the Universities of Heidelberg and then of Padua where he obtained the degree of MD in 1619 at the age of 18 . On the basis of this degree he was incorporated at Oxford in 1619 and at Cambridge in 1620. In 1629 he was made a Fellow of the College of Physicians and the following year attended Queen Henrietta Maria at the birth of the future King Charles II. Following the death of his uncle in 1631, his appointment as court physicianaccoucheur was confirmed in 1632. Dr Peter had a high opinion of himself and was flamboyant in his dress for which he was on one occasion admonished by the College authorities. He was well travelled and spoke most European languages. His reputation as a practitioner must have been considerable, for the Czar of Russia wrote to Charles I asking if he might enter his service, a request the King declined.

Dr Peter was extensively engaged in midwifery and gave lectures to the Barber Surgeons on anatomy. In 1634 he too petitioned the King for permission to create a Corporation of London Midwives with himself as president and examiner so that order might be settled by the State for their instructions and government. In this endeavour, badly needed though it was, he was opposed once more by the College of Physicians and also by the midwives themselves who defended their independence, stating:

"Neither can Dr Chamberlane teach the art of midwifery in most births because he hath no experience in itt but by reading and it must bee continuall practise in this kind that will bringe experience, and those women that desire to learn must be present at the deliv'y of many women and see the worke and behaviour of such as be skilfull midwifes who will shew and direct them and resolve their doubts.

And rather Dr Chamberlane's work and the work belonging to midwifes are contrary one to the other for he deliv's none without the use of instruments by extraordinary violence in desperate occasions, which women never practised nor desyred for they have neither parts nor hands for that art."

The petition was referred to the Bishops by the King. They not only turned it down but snubbed Dr Peter by demanding that he should forthwith apply to the Lord Bishop of London for a licence to practise midwifery.

During the era of the Commonwealth Dr Peter retired to Woodham Mortimer Hall, an estate that he had bought at Malden in Essex. There he became increasingly eccentric, writing pamphlets on religious, political, and economic subjects. His projects included suggestions for founding a public bank and bringing about a union of the Churches. In 1649 he succeeded in obtaining from the Lords an ordinance granting him the monopoly of making baths and bath-stoves for 14 years. Once again he was opposed by the College of Physicians and when he disregarded a summons to appear at the College, was dismissed from his Fellowship (1649).

Following the restoration of the monarchy, Dr Peter reminded Charles II that he was the only surviving physician to their Majesties "before the misrule." In 1661 he was reappointed Physician in Ordinary to the King and subsequently attended Queen Katherine.

Dr Peter had first married Jane Myddelton by whom he had two daughters and 11 sons, three of whom, Hugh, Paul, and John all practised midwifery. After Jane's death Peter married Ann Harrison by whom he had a further five children. He died in 1683 at the age of 82 and was buried in the churchyard at Woodham Mortimer.

Dr Peter's eldest son, known as Hugh the elder, was born in 1630 and also practised midwifery, although there is no record of where or when he qualified as a doctor. In 1670 he visited Paris, hoping to raise funds by selling the secret of the family forceps to the French government. Francois Mauriceau set him the task of delivering a 38 year old rhachitic dwarf with a grossly deformed pelvis who was in obstructed labour. Having failed, Hugh returned to London with his forceps unsold, but also with a copy of Mauriceau's recent text, Observations sur la gross esse et l'accouchement, published in 1668. This he translated and published in England in 1672 with the title of The Accomplish't Midwife. In the foreword Hugh made reference to the family secret:

"My father, brothers and my self (tho' none else in Europe as I know) have, by God's blessing and our industry, attain'd to and long practis'd a way to deliver women in this case (obstructed labour), without any prejudice to them or their infants: tho' all others (being oblig'd for want of such an expedient 


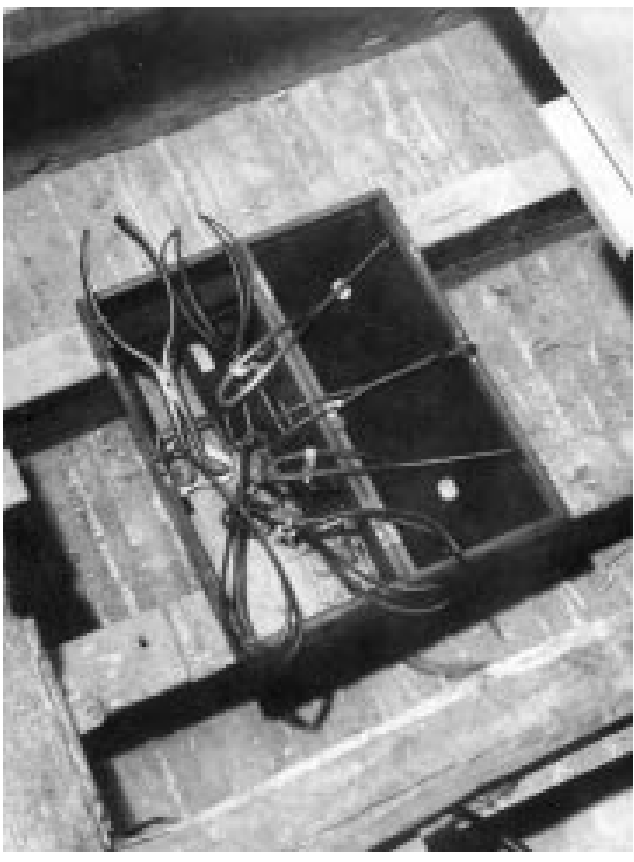

Figure 3 Dr Peter Chamberlen's obstetric instruments found beneath the floorboards in the attic of Woodham Mortimer Hall in 1813.

to use the common way) do and must endanger, if not destroy one or both with hooks ... I will now take leave to offer an apology for not publishing the secret I mention we have to extract children without hooks, where other artists use them, viz., there being my father and two brothers living that practise this art. I cannot esteem it my own to dispose of, nor publish it without injury to them."

Mauriceau's book had an immediate and lasting impact on British obstetrics and went through many editions over the next 100 years. It also brought Hugh to prominence and procured him a large practice. The following year, 1673, he was appointed Physician in Ordinary to King Charles II and subsequently also attended King James II's wife, Mary, and also the future Queen Anne. In 1685 he was elected a Fellow of the Royal Society.

In the political troubles of the time Hugh was on the side of James II, and when James came to the throne in 1686, Hugh received a pardon for "all treasons." Interestingly, and possibly not a coincidence, but two years later when the King was forced to abdicate, Hugh was accused by the College of Physicians of practising without a licence. He left for Holland where he spent the next five years. While there, he probably sold some obstetric instruments, including his lever, to Van Roonhuyze, a Dutch obstetrician.

In 1690 Hugh brought forward a proposal similar to his father's, to make England rich and happy by means of a great Land Bank. Indeed the project was launched, but after brief popularity it failed, and in debt, Hugh left for Scotland. While there in 1694 he published a work on the practise of physick in which he advocated the introduction of a health insurance scheme for the rich as well as the poor.
For a small yearly sum the insured would be attended by approved skilful physicians and surgeons, furnished with the necessary medicines for all diseases, except the pox, midwifery, and the stone, for which a supplementary charge would be made. Another 254 years were to pass before the National Health Service was introduced in the UK in 1948. Another of Hugh's great schemes, published in 1702 also while he was in Scotland, had the title: The great advantages to both Kingdoms of Scotland and England by an Union. The concise and logical way in which he argued the case may well have influenced the actual advent of the Union in 1707. Hugh is said to have lived to the age of 90, but no details of his death are known.

Hugh the younger, born in 1664, was the eldest son of Hugh the elder and his wife Dorothy Brett. Educated at Trinity College, Cambridge, where he graduated AM in 1683, Hugh completed his medical training in Leydon, before receiving the Cambridge degree of MD in 1689 at the age of 25 . He became a Fellow of the College of Physicians in 1694 and was regarded highly, becoming a Censor on three occasions. He married three times, having three daughters by his first wife. In his later years Hugh was on intimate terms with the Duchess of Buckingham (after the Duke's death), and following Hugh's death in 1728, the young Duke erected a monument to his memory in Westminster Abbey.

Having no male heir, it is likely that Hugh the younger allowed the family secret to leak out during the last few years of his life. This indeed was the view of his young contemporary, William Smellie. Certainly obstetric forceps very similar to those of the Chamberlens' came into general use after Edmund Chapman had made public his design in 1733 and William Gifford's modification had been published in 1734 .

In 1813 the obstetric instruments of $\mathrm{Dr}$ Peter Chamberlen, including five pairs of obstetric forceps, were discovered under the floorboards in the attic in his old home, Woodham Mortimer Hall (fig 3), where they had been hidden by his wife Ann on his death 130 years earlier. The forceps blades were of metal, fenestrated, and remarkably well formed. When viewed in profile each blade was straight but had a cranial curve for grasping the head. The edges of the blades were rounded. Each blade was separate to allow independent application. The lock was a fixed pivot on one blade which fitted into a hole in the other. In one pair there was merely a hole in each lock through which a cord could be passed and then wound round the shanks of the blades to fasten them together. These instruments are now in the posession of the Royal College of Obstetricians and Gynaecologists in London.

\footnotetext{
1 Aveling JH. The Chamberlens and the midwifery forceps. Lon-

2 Cutter IS, Viets HR. A short history of midwifery. Philadelphia: WB Saunders, 1964: 44-56.

3 Graham H. Eternal Eve. London: William Heinemann Medical Books Ltd, 1950 .

4 Munk W. The Roll of the Royal College of Physicians of London, 2nd Edn. Vol I. 1878. RCP, London.

5 Spencer HR. The history of British midwifery. London: John Bale, Sons and Danielsson, 1927.
} 